\title{
PENGARUH PEMBERIAN JUS MENTIMUN DAN TOMAT TERHADAP TEKANAN DARAH PEREMPUAN OVERWEIGHT DAN OBESITAS.
}

\author{
Alina Dzulchilda Ilma, Yekti Wirawanni ${ }^{*}$ \\ Program Studi Ilmu Gizi Fakultas Kedokteran Universitas Diponegoro \\ Jl.Dr.Sutomo No.18, Semarang, Telp (024) 8453708, Email : gizifk@ undip.ac.id
}

\begin{abstract}
Background: Overweight and obesity are the risk factor of hypertension on every age of life. Intake modification with high kalium and magnesium food, such as cucumber and tomato, is one of the complementary therapy to decrease the blood pressure. The objective of this study was to determine the effect of cucumber and tomato juice on blood pressure in overweight and obese women.

Method: This study was a true experimental with control group pre-post test design. Subjects were 38 women of Nutrition Science Diponegoro University students with systolic blood pressure $\geq 120 \mathrm{mmHg}$ and diastolic blood pressure $\geq 80 \mathrm{mmHg}$. They were divided into 2 groups which are, control group and intervention group. The intervention group received 100 gram of cucumber and tomato juice for about $200 \mathrm{ml} /$ day within 7 days. Saphiro-wilk used to test the normality, while Mann-Whitney, independent t-test, dependent t-test dan Wilcoxon used to do the statistical analysis.

Result: There was a decrease of systolic and diastolic blood pressure of 17,84 $\pm 9,09 \mathrm{mmHg}(\mathrm{p}=0,000)$ and 11,34 $\pm 4,02$ $\mathrm{mmHg}(p=0,000)$, while there was no significant differences on systolic and diastolic blood pressure of control group. Conclusion: Seven days consumption of $200 \mathrm{ml}$ cucumber and tomato juice can decrease systolic and diastolic blood pressure significantly in overweight and obese women.
\end{abstract}

Key words: Cucumber, tomato, blood pressure, overweight and obese woman.

\begin{abstract}
ABSTRAK
Latar Belakang : Overweight dan obesitas merupakan faktor risiko terjadinya hipertensi pada semua usia. Modifikasi asupan dengan bahan makanan tinggi kalium dan magnesium menjadi terapi untuk menurunkan tekanan darah, seperti mentimun dan tomat. Penelitian ini bertujuan membuktikan pengaruh jus mentimun dan tomat terhadap tekanan darah perempuan overweight dan obesitas.

Metode : Jenis penelitian ini adalah true experimental dengan rancangan control group pre-post test. Subjek sebanyak 38 orang terdiri dari mahasiswi Ilmu Gizi Universitas Diponegoro dengan tekanan darah sistolik $\geq 120$ $\mathrm{mmHg}$ dan diastolik $\geq 80 \mathrm{mmHg}$. Subyek dibagi menjadi 2 kelompok, yaitu kelompok kontrol dan perlakuan. Kelompok perlakuan mendapat jus mentimun dan tomat yang terbuat dari masing-masing 100 gram sebanyak $200 \mathrm{ml} / \mathrm{hari}$ selama 7 hari. Uji normalitas menggunakan Shapiro-Wilk dan analisis statisitik menggunakan uji Mann-Whitney, independent t-test, dependent t-test dan Wilcoxon.

Hasil : Kelompok perlakuan mengalami penurunan tekanan darah sistolik dan diastolik sebesar 17,84 $\pm 9,09 \mathrm{mmHg}$ $(p=0,000)$ dan 11,34 4,02 mmHg ( $p=0,000)$, dibandingkan pada kelompok kontrol yang tidak terdapat penurunan tekanan darah sistolik maupun diastolik secara signifikan.

Kesimpulan : Konsumsi 200 ml jus mentimun dan tomat selama 7 hari dapat menurunkan tekanan darah sistolik dan diastolik pada perempuan overweight dan obesitas secara signifikan.

Kata Kunci : Mentimun, tomat, tekanan darah, perempuan overweight dan obesitas.

\section{PENDAHULUAN}

Hipertensi merupakan penyebab kematian nomor 3 di Indonesia setelah stroke dan tuberkulosis, yakni mencapai $6,7 \%$ dari total kematian pada semua umur. ${ }^{1}$ Hasil Riskesdas tahun 2013 menunjukkan prevalensi hipertensi pada umur $\geq 18$ tahun secara nasional mencapai $26,5 \%{ }^{2}$ Persentase hipertensi pada individu yang overweight dan obesitas sebesar $24,5 \%$ dan $27,5 \%$, jauh lebih tinggi dibandingkan dengan individu yang mempunyai berat badan normal $(12,5 \%){ }^{3}$ Prevalensi obesitas tahun 2013 pada perempuan dewasa ( $>18$ tahun) sebesar 32,9\%, naik 17,5\% dari tahun 2010. Angka prevalensi ini jauh lebih tinggi

dibanding prevalensi obesitas pada laki-laki dewasa (>18 tahun) yaitu $19,7 \% .^{2}$ Pada populasi mahasiswi Program Studi Ilmu Gizi Undip ditemukan sekitar $17,5 \%$ memiliki status gizi overweight dan obesitas. Overweight dan obesitas merupakan salah satu faktor determinan terjadinya hipertensi pada semua usia. Risiko hipertensi pada seseorang yang mengalami overweight adalah 2 hingga 6 kali lebih tinggi dibanding seseorang dengan berat badan normal. ${ }^{4}$ Resistensi insulin dan gangguan fungsi endotel pembuluh darah yang terjadi pada obesitas akan menyebabkan vasokontriksi dan reabsorpsi natrium di ginjal yang akhirnya mengakibatkan tekanan darah meningkat atau hipertensi. ${ }^{5}$
\end{abstract}

${ }^{*}$ Penulis Penanggungjawab 
Modifikasi asupan makanan yang mengandung tinggi kalium, magnesium, dan serat, serta rendah natrium merupakan salah satu cara untuk mengurangi faktor risiko terjadinya peningkatan tekanan darah. Kalium menghambat pelepasan renin dengan mengurangi natrium dalam urin dan air dengan cara yang sama seperti diuretik. $^{6-7}$ Magnesium akan mempengaruhi stimulus di pusat saraf simpatetis agar vasokontriksi tidak melewati batas yang dibutuhkan. ${ }^{8-9}$ Kedua mikronutrien ini juga berperan dalam sistem reninangiotensin (RAS) yang menjadi pusat kontrol utama tekanan darah dan fungsi endokrin terkait kardiovaskuler. ${ }^{10}$ Bahan makanan dengan komposisi zat gizi yang sinergis membantu menurunkan tekanan darah yaitu mentimun (Cucumis sativus L.) dan tomat (Lycopersicum commune).

Dalam 100 gram tomat memiliki kandungan kalium sebanyak $235 \mathrm{mg}$ dan serat sebanyak 0,9 g. Penelitian tahun 2012 pada 34 wanita postmenopause hipertensi membuktikan dengan pemberian $200 \mathrm{ml} /$ hari jus tomat selama 7 hari dapat menurunkan tekanan darah sistolik dan diastolik sebesar 7,276-11,76 $\mathrm{mmHg}$ dan 3,3218,82 mmHg. ${ }^{11}$ Penelitian tahun 2014 pada 38 penderita hipertensi menunjukkan bahwa pemberian 100 gram mentimun yang setara dengan kalium dan magnesium sebanyak $147 \mathrm{mg}$ dan $13 \mathrm{mg}$ selama 7 hari dapat menurunkan tekanan darah sistolik dan diastolik sebesar $12 \%$ dan $10,4 \%$ dibanding kelompok kontrol. ${ }^{12}$ Penelitian yang lain tahun 2007 di Pasuruan, Jawa Timur, yang dilakukan pada 28 penderita hipertensi usia 35-55 tahun baik perempuan maupun laki-laki yang diberi $200 \mathrm{ml} /$ hari jus belimbing dan mentimun selama 14 hari dapat menurunkan tekanan darah sistolik dan diastolik sebesar 14,21 mmHg dan 11,36 mmHg. ${ }^{13}$

Mentimun dan tomat memiliki kandungan energi, karbohidrat, dan gula paling rendah dibandingkan dengan pangan sumber kalium dan magnesium lainnya (pisang, belimbing, semangka, dan pepaya), ${ }^{14}$ dan yang paling memungkinkan dikonsumsi dalam jumlah banyak oleh subjek overweight dan obesitas.

Beberapa penelitian telah membuktikan pengaruh jus mentimun maupun jus tomat terhadap tekanan darah. Namun, belum ditemukan penelitian yang menggabungkan efektivitas jus mentimun dan tomat untuk menurunkan tekanan darah terutama pada subjek overweight dan obesitas. Oleh karena itu, penelitian ini bertujuan untuk menganalisis pengaruh pemberian jus mentimun (Cucumis sativus) dan tomat (Lycopersicum commune) terhadap tekanan darah pada perempuan overweight dan obesitas.

\section{METODE PENELITIAN}

Penelitian dilakukan di Program Studi Ilmu Gizi Universitas Diponegoro Semarang pada bulan Mei 2015. Penelitian ini merupakan penelitian true experimental dengan rancangan pre test - post test control group design dan termasuk dalam ruang lingkup gizi klinis. Subjek penelitian adalah mahasiswi Program Studi Ilmu Gizi Universitas Diponegoro Semarang dengan kriteria inklusi berusia 18-24 tahun, IMT $\geq 23 \mathrm{~kg} / \mathrm{m}^{2}$, memiliki tekanan darah $\geq 120 / 80 \mathrm{mmHg}$, tidak sedang mengonsumsi obat-obatan antihipertensi, tidak dalam keadaan sakit atau dalam perawatan dokter, dan bersedia menjadi subjek penelitian dengan mengisi informed consent. Subjek dikeluarkan dari penelitian bila tidak patuh terhadap intervensi yang diberikan selama penelitian, sakit saat penelitian berlangsung dan tidak bisa mengikuti penelitian sampai akhir.

Perhitungan subjek penelitian menggunakan rumus uji hipotesis terhadap rerata dua populasi independen dan dibutuhkan sebanyak 38 subjek. Penentuan subjek penelitian menggunakan metode consecutive sampling. Subjek dibagi menjadi 2 kelompok dengan metode simple randomization, yang terdiri atas kelompok kontrol dan kelompok perlakuan, masing-masing kelompok terdiri dari 19 subjek. Kelompok perlakuan mendapatkan jus mentimun dan tomat sebanyak $200 \mathrm{ml} / \mathrm{hari}$ dan kelompok kontrol mendapatkan plasebo yang terbuat dari air sirup 0 kalori $200 \mathrm{ml} / \mathrm{hari}$.

Pemberian jus dan plasebo dilakukan selama 7 hari. Asupan makan sehari-hari pada kelompok kontrol dan kelompok perlakuan dikontrol. Pencatatan makan dilakukan selama intervensi. Kepatuhan subjek mengonsumsi jus dan plasebo dicatat dengan menggunakan formulir kepatuhan. Cara membuat jus mentimun dan tomat yaitu mentimun dan tomat yang sudah dibersihkan sebanyak masing-masing 100 gram yang dicampur dengan air $50 \mathrm{ml}$ dan sirup 0 kalori. Mentimun yang sudah dibersihkan dicampur dengan tomat yang sudah dibersihkan dan di-blanching dengan air pada suhu $70-90^{\circ} \mathrm{C}$ selama 10 menit, kemudian diblender tanpa dilakukan penyaringan agar kandungan seratnya tidak berkurang.

Penelitian pendahuluan diawali dengan melakukan uji kandungan nilai zat gizi dalam 200 ml jus mentimun dan tomat yang terbuat dari masing-masing $100 \mathrm{~g}$ mentimun dan tomat yang dilakukan di Laboratorium Gizi dan Teknologi 
Pangan Universitas Muhammadiyah Semarang. Uji kandungan nilai zat gizi ini meliputi energi, karbohidrat, protein, lemak, serat, natrium, kalium, magnesium, serta indeks glikemik.

Variabel bebas adalah jus mentimun dan tomat. Variabel terikat adalah tekanan darah sistolik dan diastolik yang diukur dengan sphygmomanometer digital. Sedangkan variabel perancu adalah asupan natrium, kalium, magnesium, dan serat yang diperoleh dengan metode food recall selama 7 hari dan diolah menggunakan nutrisurvey.

Karakteristik subjek dianalisis menggunakan analisis deskriptif. Untuk menguji kenormalan data menggunakan uji Shapiro-Wilk. Perbedaan tekanan darah sistolik dan diastolik sebelum dan sesudah intervensi menggunakan dependent t-test untuk kelompok perlakuan dan menggunakan uji Wilcoxon untuk kelompok kontrol. Perbedaan pengaruh perlakuan kedua kelompok terhadap tekanan darah sistolik dan diastolik dianalisis dengan menggunakan uji Mann Whitney.

\section{HASIL PENELITIAN}

Hasil skrining awal yang diikuti oleh 70 mahasiswi Program Studi Ilmu Gizi Universitas Diponegoro Semarang menunjukkan sebanyak 5 $(7,14 \%)$ mahasiswi berstatus gizi normal, 20 $(28,57 \%)$ mahasiswi mengalami overweight dan 45 (64,29\%) mahasiswi mengalami obesitas. Dari 65 mahasiswi yang tergolong overweight dan obesitas, $23(35,38 \%)$ mahasiswi di antaranya termasuk dalam normotensi, $36(55,38 \%)$ mahasiswi di antaranya termasuk dalam prahipertensi dan 6 $(9,23 \%)$ mahasiswi termasuk dalam hipertensi I.

\section{Penelitian Pendahuluan}

Penelitian pendahuluan dilakukan untuk menguji kandungan nilai gizi seperti energi, karbohidrat, protein, lemak, serat, natrium, kalium, magnesium, serta indeks glikemik dari jus mentimun dan tomat. Hasil uji kandungan nilai gizi dalam $200 \mathrm{ml}$ jus yang terbuat dari $100 \mathrm{~g}$ mentimun, $100 \mathrm{~g}$ tomat, $50 \mathrm{ml}$ air, dan sirup 0 kalori disajikan dalam tabel 1 .

Tabel 1. Kandungan Zat Gizi Jus Mentimun dan Tomat

\begin{tabular}{lc}
\hline \multicolumn{1}{c}{ Kandungan Gizi } & Jumlah \\
\hline Energi & $19,84 \mathrm{kkal}$ \\
Karbohidrat & $3,18 \mathrm{~g}$ \\
Protein & $1,24 \mathrm{~g}$ \\
Lemak & $0,30 \mathrm{~g}$ \\
Serat & $1,56 \mathrm{~g}$ \\
Kalium & $169,50 \mathrm{mg}$ \\
Magnesium & $16,76 \mathrm{mg}$ \\
Natrium & $3,45 \mathrm{mg}$ \\
Indeks Glikemik & 29 \\
\hline
\end{tabular}

Tabel 1 menunjukkan bahwa dalam $200 \mathrm{ml}$ jus yang terbuat dari masing-masing $100 \mathrm{~g}$ mentimun dan tomat mengandung $169,50 \mathrm{mg}$ kalium, $16,76 \mathrm{mg}$ magnesium, dan 1,56 g serat. Hasil ini lebih tinggi jika dibandingkan dengan kandungan kalium, magnesium, dan serat pada mentimun atau tomat saja.

\section{Karakteristik Subjek}

Karakteristik subjek yang terdiri dari gambaran status gizi dan tekanan darah sistolik dan diastolik subjek sebelum penelitian disajikan dalam tabel 2 .

Tabel 2. Karakteristik Subjek

\begin{tabular}{|c|c|c|c|c|c|c|c|}
\hline \multirow[t]{2}{*}{ Karakteristik subjek } & \multicolumn{3}{|c|}{$\begin{array}{c}\text { Perlakuan } \\
(n=19)\end{array}$} & \multicolumn{3}{|c|}{$\begin{array}{c}\text { Kontrol } \\
(\mathrm{n}=19)\end{array}$} & \multirow[t]{2}{*}{$p$} \\
\hline & Mean \pm SD & $\mathbf{n}$ & $\%$ & Mean \pm SD & $\mathbf{n}$ & $\%$ & \\
\hline \multicolumn{8}{|l|}{ Usia (tahun) } \\
\hline $18-20$ & $20,05 \pm 1,18$ & 13 & 68,42 & $20,74 \pm 1,45$ & 9 & 47,37 & 0,183 \\
\hline 21-23 & & 6 & 31,58 & & 10 & 52,63 & \\
\hline \multicolumn{8}{|l|}{ Status Gizi } \\
\hline Overweight $\left(23-24,9 \mathrm{~kg} / \mathrm{m}^{2}\right)$ & $26,54 \pm 2,27$ & 7 & 36,84 & $27,86 \pm 5,00$ & 8 & 42,10 & 0,759 \\
\hline Obesitas $\left(\geq 25 \mathrm{~kg} / \mathrm{m}^{2}\right)$ & & 12 & 63,16 & & 11 & 57,89 & \\
\hline \multirow{2}{*}{$\begin{array}{l}\text { Tekanan Darah Sistolik }(\mathrm{mmHg}) \\
\text { Tekanan Darah Diastolik (mmHg) }\end{array}$} & $132,89 \pm 7,15$ & & & $127,82 \pm 7,87$ & & & 0,015 \\
\hline & $90,42 \pm 5,79$ & & & $84,87 \pm 4,38$ & & & 0,003 \\
\hline
\end{tabular}

Uji beda Mann-Whitney 
Subjek dalam penelitian merupakan perempuan berusia antara 18-23 tahun dan sebagian besar memiliki status gizi obesitas baik kelompok perlakuan maupun kontrol. Hasil uji beda terhadap usia dan status gizi kelompok perlakuan maupun kontrol menunjukkan tidak ada perbedaan antara kedua kelompok $(p>0,05)$. Terdapat perbedaan rerata tekanan darah sistolik $(p=0,015)$ dan diastolik $(p=0,003)$ sebelum intervensi pada kedua kelompok.

\section{Asupan Makan Selama Intervensi}

Asupan energi, protein, lemak, karbohidrat, natrium, kalium, magnesium, dan serat dapat mempengaruhi tekanan darah sistolik maupun diastolik. Asupan makan subjek selama intervensi dapat dilihat pada tabel 3.

Tabel 3. Asupan makan selama intervensi

\begin{tabular}{lccc}
\hline & $\begin{array}{c}\text { Perlakuan }(\mathbf{n}=19) \\
(\text { Mean } \pm \text { SD) }\end{array}$ & $\begin{array}{c}\text { Kontrol(n=19) } \\
(\text { Mean } \pm \text { SD) }\end{array}$ & $p$ \\
\hline Energi (kkal) & $1691,80 \pm 202,65$ & $1644,20 \pm 203,06$ & $0,474^{2}$ \\
Protein (g) & $62,08 \pm 13,23$ & $55,89 \pm 8,64$ & $0,097^{2}$ \\
Lemak (g) & $55,40 \pm 16,83$ & $59,88 \pm 20,97$ & $0,473^{2}$ \\
Karbohidrat (g) & $238,65 \pm 68,44$ & $226,69 \pm 58,01$ & $0,568^{2}$ \\
Natrium (mg) & $1269,60 \pm 161,34$ & $1284,60 \pm 213,24$ & $0,942^{1}$ \\
Kalium (mg) & $1433,30 \pm 274,85$ & $1237,80 \pm 273,88$ & $0,035^{2}$ \\
Magnesium (mg) & $200,64 \pm 24,28$ & $177,39 \pm 51,10$ & $0,002^{1}$ \\
Serat (g) & $10,97 \pm 3,43$ & $10,07 \pm 2,96$ & $0,448^{1}$ \\
\hline
\end{tabular}

1. Uji beda Mann-Whitney

Uji beda independent $t$-test

Berdasarkan hasil uji beda, tidak ada perbedaan asupan energi, protein, lemak, karbohidrat, natrium, dan serat antara kedua kelompok $(p>0,05)$, tetapi terdapat perbedaan asupan kalium $(p=0,035)$ dan magnesium $(p=0,002)$. Rerata asupan kalium dan magnesium pada kelompok perlakuan lebih tinggi daripada kelompok kontrol. Hal ini dikarenakan adanya peningkatan asupan kalium dan magnesium yang berasal dari jus mentimun dan tomat pada kelompok perlakuan.

Pengaruh Pemberian Jus Mentimun dan Tomat terhadap Tekanan Darah Sistolik dan Diastolik

Pengaruh pemberian jus mentimun dan tomat terhadap tekanan darah sistolik dan diastolik disajikan dalam tabel 4

Tabel 4. Pengaruh Pemberian Jus Mentimun dan Tomat terhadap Tekanan Darah Sistolik dan Diastolik

\begin{tabular}{lccc}
\hline \multicolumn{1}{c}{ Variabel } & Perlakuan $(\mathbf{n}=\mathbf{1 9})$ & Kontrol $(\mathbf{n}=\mathbf{1 9})$ & \multirow{2}{*}{$\boldsymbol{p}^{3}$} \\
\cline { 2 - 3 } & Mean \pm SD & Mean $\mathbf{S D}$ & \\
\cline { 1 - 3 } Tekanan Darah Sistolik (mmHg) & & & \\
Awal & $132,89 \pm 7,15$ & $127,82 \pm 7,87$ & \\
Akhir & $115,05 \pm 8,94$ & $128,39 \pm 7,77$ & \\
$\boldsymbol{\Delta}$ & $-17,84 \pm 9,09$ & $0,58 \pm 2,32$ & 0,000 \\
$\boldsymbol{p}$ & $0,000^{1}$ & $0,552^{2}$ & \\
\hline Tekanan Darah Diastolik (mmHg) & & & \\
Awal & $90,42 \pm 5,79$ & $84,87 \pm 4,38$ & \\
Akhir & $79,08 \pm 4,60$ & $86,08 \pm 4,56$ & \\
$\boldsymbol{\Delta}$ & $-11,34 \pm 4,02$ & $1,21 \pm 3,38$ & 0,000 \\
$\boldsymbol{P}$ & $0,000^{1}$ & $0,135^{2}$ & \\
\hline
\end{tabular}

1. Uji dependent t-test

2. Uji beda Wilcoxon

3. Uji Mann-Whitney

Hasil uji beda pada tabel 4 menunjukkan adanya perbedaan tekanan darah sistolik dan diastolik yang bermakna pada sebelum dan sesudah perlakuan $(p=0,000)$, sedangkan tekanan darah sistolik dan diastolik pada kelompok kontrol tidak mengalami perubahan bermakna $(p>0,05)$.

Perbedaan rerata perubahan tekanan darah sistolik dan diastolik antar kedua kelompok dianalisis dengan uji Mann-Whitney, terdapat perbedaan rerata perubahan tekanan darah sistolik dan diastolik yang bermakna antara kelompok perlakuan dan kelompok kontrol $(p=0,000)$.

\section{PEMBAHASAN}

Penelitian pendahuluan dilakukan untuk menguji kandungan zat gizi jus mentimun dan 
tomat. Hasilnya menunjukkan bahwa kandungan kalium, magnesium dan serat dalam jus mentimun dan tomat yaitu sebesar $169,50 \mathrm{mg}, 16,76 \mathrm{mg}$ dan $1,56 \mathrm{~g}$, lebih tinggi dibanding kandungan di dalam mentimun atau tomat saja.

Seluruh subjek dalam penelitian ini berjenis kelamin perempuan, karena perempuan lebih rentan mengalami kegemukan yang disebabkan oleh komposisi lemak tubuh yang lebih tinggi dan aktivitas fisik yang lebih rendah. Karakteristik subjek sebagian besar memiliki status gizi obesitas. Prevalensi obesitas pada orang dewasa maupun anak-anak dan remaja di seluruh dunia mengalami peningkatan secara progresif baik pada negara berkembang maupun negara maju. ${ }^{15}$ Menurut Institut Kesehatan Nasional Amerika (NIH), status gizi obesitas meningkatkan risiko hipertensi menjadi dua sampai enam kali lipat. ${ }^{4}$ Obesitas dapat meningkatkan volume plasma dan curah jantung yang akhirnya mengakibatkan terjadinya peningkatan tekanan darah. Peningkatan berat badan sekitar $10 \%$ akan menyebabkan kenaikan tekanan darah sebesar $7 \mathrm{mmHg} .{ }^{16}$ Obesitas juga berhubungan dengan aktivitas renin-angiotensin, hiperinsulinemia, dan peningkatan aktivitas sistem saraf simpatetik, dan semua ini berkontribusi pada reabsorpsi natrium dan berhubungan dengan retensi cairan sehingga menyebabkan terjadinya hipertensi obesitas renal. $^{5}$

Obesitas merupakan suatu masalah yang serius pada masa remaja maupun dewasa. Seiring meningkatnya kejadian obesitas, dikenal sindrom metabolik yang terdiri dari obesitas sentral, peningkatan kadar trigliserida, penurunan kadar kolesterol high density lipoprotein (HDL), resistensi insulin, dan hipertensi. Pada obesitas terjadi resistensi insulin dan gangguan fungsi endotel pembuluh darah yang menyebabkan vasokonstriksi dan reabsorpsi natrium di ginjal sehingga mengakibatkan terjadinya hipertensi. Resistensi insulin dapat meningkatkan tekanan darah melalui penurunan nitric oxide (NO) yang memicu terjadinya vasokonstriksi, peningkatan sensitivitas garam, atau peningkatan volume plasma. ${ }^{16}$

Berdasarkan hasil uji statistik ditemukan adanya penurunan tekanan darah sistolik dan diastolik yang bermakna pada kelompok perlakuan sebelum dan sesudah intervensi. Hal ini menunjukkan adanya pengaruh pemberian jus mentimun dan tomat sebanyak $200 \mathrm{ml}$ selama 7 hari pada kelompok perlakuan. Perbedaan tekanan darah sistolik dan diastolik terjadi disebabkan adanya perbedaan asupan kalium dan magnesium antara kelompok kontrol dan perlakuan.
Hasil penelitian menunjukkan pada kelompok perlakuan terjadi perubahan tekanan darah sistolik dengan rata-rata penurunan sebesar $17,84 \pm 9,09 \mathrm{mmHg}$ dan tekanan darah diastolik dengan rata-rata penurunan sebesar 11,34 \pm 4,02 mmHg. Pada kelompok kontrol tidak terdapat penurunan yang signifikan baik tekanan darah sistolik maupun diastolik. Penelitian tahun 2012 pada 34 wanita postmenopause hipertensi membuktikan dengan pemberian $200 \mathrm{ml} / \mathrm{hari}$ jus tomat selama 7 hari dapat menurunkan tekanan darah sistolik dan diastolik sebesar 7,276-11,76 mmHg dan 3,321-8,82 mmHg. ${ }^{11}$ Penelitian tahun 2014 pada 38 penderita hipertensi menunjukkan bahwa pemberian 100 gram mentimun yang setara dengan kalium dan magnesium sebanyak $147 \mathrm{mg}$ dan $13 \mathrm{mg}$ selama 7 hari dapat menurunkan tekanan darah sistolik dan diastolik sebesar 15,85 $\pm 7,77$ dan $8,455 \pm 6,19$ dibanding kelompok kontrol. $^{12}$ Berdasarkan hasil penelitian yang telah dilakukan dapat diketahui bahwa pemberian jus mentimun dan tomat dapat memberikan efek penurunan tekanan darah sistolik dan diastolik lebih banyak dibanding pemberian jus mentimun atau tomat saja.

Rerata asupan makan subjek diperoleh melalui metode recall yang dilakukan selama penelitian berlangsung yaitu 7 hari. Berdasarkan hasil recall tersebut dapat diketahui bahwa tingkat kecukupan kalium dan magnesium baik kelompok perlakuan maupun kontrol masih belum memenuhi standar AKG 2013. Asupan kalium dikatakan cukup menurut AKG 2013 yaitu sebanyak 4700 mg, dimana anjuran ini sama dengan yang dikemukakan oleh International Food Information Council Foundation. ${ }^{17-18}$ Kecukupan magnesium menurut AKG 2013 sebanyak 320 mg untuk perempuan. ${ }^{17}$ Rerata asupan kalium subjek selama intervensi yaitu 1433,30 mg pada kelompok perlakuan dan $1237,80 \mathrm{mg}$ pada kelompok kontrol. Nilai ini memenuhi $30,1 \%$ dari angka kecukupan.

Diet rendah kalium dapat menyebabkan hipertensi serta memicu terjadinya defisiensi kalium dalam tubuh sebagai akibat dari kurangnya simpanan kalium dalam ginjal dan hilangnya kalium melalui feses dan urin. ${ }^{19}$ Kalium sebanyak $169,50 \mathrm{mg}$ yang terdapat di dalam jus mentimun dan tomat memilik efek antihipertensif dengan berbagai cara, antara lain yaitu natriuretik atau menghambat penyerapan kembali natrium di tubulus renal proksimal dan menekan pengeluaran renin sehingga menyebabkan peningkatan pengeluaran natrium dan cairan melalui urin. ${ }^{7}$

Asupan kalium dalam jumlah cukup dapat menurunkan sensitivitas vasokonstriksi pada norepinefrin dan angiotensin II sehingga dapat 
mengurangi retensi natrium dan cairan dengan cara menghambat pelepasan renin yang bertugas mengubah angiotensinogen menjadi angiotensin I. Pelepasan renin yang dihambat oleh kalium menyebabkan angiotensin I tidak dapat diubah oleh Angiotensin Converting Enzyme (ACE) menjadi bentuk aktifnya yaitu angiotensin II yang bersifat sebagai vasokonstriktor dan dapat merangsang pengeluaran aldosteron yang menyebabkan retensi natrium. Selain itu, kalium juga mempertahankan fungsi sel pembuluh endotel melalui peningkatan produksi NO yang berpengaruh terhadap penurunan tekanan darah sistolik maupun diatolik dengan cara vasodilatasi atau relaksasi otot halus pembuluh darah. $^{6,20}$

Rerata asupan natrium subjek selama intervensi kelompok perlakuan dan kelompok kontrol adalah 1269,60 mg dan 1284,60 mg. Bila dibandingkan, rasio asupan kalium : natrium pada kelompok perlakuan adalah $1,1: 1$, pada kelompok kontrol rasio yang terjadi adalah $0,9: 1$. Rasio asupan kalium-natrium yang dianjurkan adalah 5:1 dimana jumlah kalium dan natrium yang dianjurkan adalah $120 \mathrm{mmol} / \mathrm{hari}(4700 \mathrm{mg})$ dan $60 \mathrm{mmol} / \mathrm{hari}$ (1500 mg). ${ }^{6}$ Homeostasis natrium dan kalium berperan dalam vasodilatasi-terkait-endotelium. ${ }^{19}$

Asupan magnesium subjek selama intervensi kelompok perlakuan dan kelompok kontrol adalah 200,64 mg dan 177,39 mg. Pada kelompok perlakuan, asupan magnesium sudah memenuhi 62,7\% kebutuhan berdasarkan AKG 2013. Hasil penelitian menunjukkan kandungan magnesium pada jus mentimun dan tomat sebanyak 16,76 mg dimana lebih tinggi dibanding kandungan di dalam mentimun atau tomat saja. Magnesium merupakan vasodilator dalam pengaturan tekanan darah dan juga sebagai inhibitor dari kontraksi otot polos pembuluh darah. Asupan magnesium yang inadekuat menyebabkan terjadinya penyempitan dinding arteri dan kapiler sehingga tekanan darah menjadi meningkat. Magnesium juga berperan dalam memproduksi prostasiklin vasodilator dan NO dengan cara memodulasi reaktivitas dan pergerakan pembuluh darah. ${ }^{8,20}$

Zat selain kalium dan magnesium yang mungkin berperan juga dalam menurunkan tekanan darah yaitu likopen yang dalam penelitian ini tidak diteliti. Tomat yang digunakan dalam pembuatan jus merupakan tomat utuh dengan kulit yang telah di-blanching dengan air pada suhu $70-90^{\circ} \mathrm{C}$ selama 10 menit dengan tujuan untuk meningkatkan kandungan likopen dalam tomat. Kandungan likopen dalam $100 \mathrm{~g}$ tomat yang dibuat jus sebesar $12,8 \mathrm{mg}$ sedangkan pada $100 \mathrm{~g}$ tomat segar sebanyak 5,8 mg. ${ }^{11}$ Efek antiinflamasi yang berasal dari antioksidan di dalam likopen ini dapat mengurangi kerusakan sel yang dapat memicu aterosklerosis yang mengakibatkan tekanan darah meningkat.

Likopen juga berperan dalam produksi NO di pembuluh endotel, menurunkan oksidasi LDL, dan sebagai anti-aterosklerosis dengan cara melindungi pembuluh endotel dari kerusakan, mengurangi respon inflamasi, serta menghambat proliferasi sel otot halus. ${ }^{11}$ Studi meta analisis di Australia mengenai pemberian ekstrak likopen sebanyak $\geq 25 \mathrm{mg} /$ hari efektif untuk menurunkan serum kolesterol total dan LDL serta menurunkan tekanan darah dengan perubahan tekanan darah sistolik rata-rata $5,26 \mathrm{mmHg} .{ }^{21}$ Sedangkan pada penelitian di Israel yang dilakukan kepada 31 subjek hipertensi I yang diberikan ekstrak tomat sebanyak $250 \mathrm{mg}$ yang mengandung $15 \mathrm{mg}$ likopen selama 8 minggu dapat menurunkan tekanan darah sistolik sebesar $10 \mathrm{mmHg}$ dan tekanan darah diastolik sebesar $4 \mathrm{mmHg} .{ }^{22}$

\section{SIMPULAN}

Pemberian $200 \mathrm{ml}$ jus mentimun dan tomat yang terbuat dari $100 \mathrm{~g}$ mentimun, $100 \mathrm{~g}$ tomat, 50 $\mathrm{ml}$ air dan sirup 0 kalori sebanyak satu kali dalam sehari selama 7 hari berpengaruh terhadap penurunan tekanan darah sistolik sebesar 17,84 \pm $9,09 \mathrm{mmHg}$ dan tekanan darah diastolik sebesar 11,34 \pm 4,02 $\mathrm{mmHg}$ pada perempuan overweight dan obesitas.

\section{DAFTAR PUSTAKA}

1. Hipertensi penyebab kematian nomor tiga. [editorial]; 2010. Available from: URL: HYPERLINK: http://www.dinkesjatengprov.go.id

2. Riset Kesehatan Dasar (Riskesdas) 2013. Jakarta: Departemen Kesehatan Republik Indonesia. Desember 2013.

3. Sutedjo. Profil Hipertensi pada Populasi MONICA tahun 2000 (Survey III). Kumpulan Makalah Seminar Sehari Presentasi Hasil MONICA-Jakarta 2000, Indonesia Cardiovascular Study. Jakarta, 29 Oktober 2002.

4. Chobanian AV, et al. The seventh report of the Joint National Committee on prevention, detection, evaluation, and treatment of high blood pressure the seventh report of the Joint National Committee on prevention, detection, evaluation, and treatment of high blood pressure. JAMA 2003;289;2560-72.

5. Haris $S$, Tambunan T. Hipertensi pada Sindrom Metabolik. Sari Pediatri 2009;11(4):257-63.

6. Houston MC. The Importance of Potassium in Managing Hypertension. Curr Hypertens Rep. 2011;13(4):309-17.

7. Meneton P. Potassium and it's role in reducing arterial blood pressure. [serial online] 2006 [dikutip 
pada 10 Maret 2015]. Available from: URL: HYPERLINK: http//www.ifava.org

8. Sontia B, Touyz RM. A role of magnesium in hypertension. Arch Bioch Biophys 458:33. 2006.

9. Gropper SS, Smith JL., Groff JL. Advance Nutrition and Human Metabolism. $5^{\text {th }}$ edition. 2009. Cengange Learning. Wadsworth, Belmont. California.

10. Drenjančević-Perić I., Jelaković B., Lombard J.H., Kunert M.P., Kibel A., Gros M.. High-Salt Diet and Hypertension: Focus on the Renin-Angiotensin System. Kidney Blood Press Res 2011;34:1-11. DOI: $10.1159 / 000320387$.

11. Lestari AP, Rahayuningsih HM. Pengaruh Pemberian Jus Tomat (Lycopersicum commune) terhadap Tekanan Darah pada Wanita Postmenopause Hipertensif. Journal of Nutrition College. 2012;1(1);414-20.

12. Lebalado LP, Mulyati T. Pengaruh Pemberian Jus Mentimun (Cucumis sativus L.) terhadap Tekanan Darah Sistolik dan Diastolik pada Penderita Hipertensi. Journal of Nutrition College. 2014;3(3);396-403.

13. Muniroh L., Wirjatmadi B., Kuntoro. Pengaruh Pemberian Jus Buah Belimbing dan Mentimun terhadap Penurunan Tekanan Darah Sistolik dan Diastolik Penderita Hipertensi. The Indonesian Journal of Public Health, Juli 2007: 4(1):25-34.

14. National Nutrient Database for Standard Reference, Nutrient Data No. 11205, 11695, 09326, 09226, 09040, 09060, USDA.

15. Caballero, B. The Global Epidemic of Obesity: An Overview. Epidemiologic Review. Vol. 29, 2007.

16. Brooks VL., Shi Zhiang, Holwerda SW, Fadel PJ. Obesity - induced increases in sympathetic nerve activity: sex matters. Autonomic Neuroscience: Basic and Clinical 187 (2015) 18-26. doi:10.1016/j.autneu.2014.11.006. Available from www.elsevier.com/locate/autneu.

17. Angka Kecukupan Gizi (AKG) 2013.

18. Appel, L.J. ASH Position Paper: Dietary Approaches to Lower blood Pressure. J Clin Hypertens (Greenwich) 2009;11:358-68.

19. Adrogué HJ, Madias NE. Sodium and Potassium in the Pathogenesis of Hypertension. N ENG J MED. 2007;356(19):1966-78.

20. Nelms $\mathbf{M}$, et al. Nutrition Therapy and Pathophysiology 2/e. Wadsworth: Cengage Learning, 2011.

21. Ried K, Fakler P. Protective effect of lycopene on serum cholesterol and blood pressure: Meta-analyses of intervention trials. Maturitas 68 (2011) 299-310. doi:10.1016/j.maturitas.2010.11.018. Available from www.elsevier.com/locate/maturitas

22. Engelhard YN, Gazer Benny, Paran Esther. Natural antioxidant from tomato extract reduce blood pressure in patient with grade-1 hypertension: a double blind, placebo-controlled pilot study. Am Heart J 2006;151:100.e1-100.e6. 